\title{
Superoxide dismutase and catalase activity in collared peccary (Pecari tajacu) seminal plasma and their relation to sperm quality
}

\section{Atividade da superóxido dismutase e catalase no plasma seminal de catetos (Pecari tajacu) e sua relação com a qualidade espermática}

\author{
Érika Aparecida Araújo dos Santos ${ }^{1}$; Patrícia da Cunha Sousa ${ }^{1}$; Andréia Maria da \\ Silva²; Ariana Lopes Correia Paiva²; Arthur Emannuel de Araujo Lago; ; Valéria \\ Veras de Paula ${ }^{4}$; Alexsandra Fernandes Pereira ${ }^{4}$; Arlindo de Alencar Araripe \\ Noronha Moura ${ }^{5}$; Alexandre Rodrigues Silva ${ }^{4 *}$
}

\begin{abstract}
The study of the seminal plasma help us to understand the mechanisms by which reactive oxygen species (ROS) affect the sperm. The antioxidant enzymes, as the superoxide dismutase - SOD and catalase - CAT, are capable of removing the oxidative agents before they produce injuries. The aim of the current study was to investigate the activity of antioxidant enzymes SOD and CAT in seminal plasma, and their association with sperm quality in collared peccaries. Study was conducted during the dry period (August and September) on a region characterized by a semiarid climate, with an average annual temperature of $27^{\circ} \mathrm{C}$ and irregular rainfall (Mossoro, RN, Brazil; $5^{\circ} 10^{\prime} \mathrm{S}$ and $37^{\circ} 10^{\prime} \mathrm{W}$ ). Nine ejaculates were obtained from sexually mature males (1 sample per animal) by electroejaculation. Semen was evaluated for microscopic parameters and the activity of SOD and CAT was measured by spectrophotometry. All ejaculates were white in color. Mean values for concentration were of $207 \pm 160$ $\mathrm{x} 10^{6} \mathrm{sperm} / \mathrm{mL}$, motility of $83.0 \pm 20.9 \%$ and viability of $72.5 \pm 10.4 \%$. In regards to the enzymatic activity, none was observed for the CAT enzyme. Trace levels of SOD $(0.033 \pm 0.049 \mathrm{AU} / \mathrm{mgP})$ were detected in the ejaculates of all individuals; however, no correlation was observed between SOD levels and the sperm motility $(\mathrm{R}=0.35 ; \mathrm{P}=0.931)$, vigor $(\mathrm{R}=0.29 ; \mathrm{P}=0.133)$, viability $(\mathrm{R}=0.16 ; \mathrm{P}=0.29)$, functional membrane $(\mathrm{R}=0.04 ; \mathrm{P}=0.617)$ or morphology $(\mathrm{R}=0.03 ; \mathrm{P}=0.637)$. In conclusion, we demonstrated the first description of antioxidant enzyme activity in seminal plasma of fresh ejaculates obtained from collared peccaries. SOD antioxidant activity was evident during the dry period of a semiarid region, but no relationship between SOD and semen parameters was observed.
\end{abstract}

Key words: Oxidative stress. Semen. Wild mammals. Biobank.

\section{Resumo}

O estudo do plasma seminal nos auxilia a compreender os mecanismos pelos quais as espécies reativas de oxigênio (EROs) afetam o espermatozoide. As enzimas antioxidantes, como a superóxido dismutase

Discentes, Curso de Mestrado, Programa de Pós-Graduação em Ciência Animal, PPGCA, Universidade Federal Rural do SemiÁrido, UFERSA, Mossoró, RN, Brasil. E-mail: erikasantos_vet@yahoo.com.br; pattbiovet13@gmail.com

2 Discentes, Curso de Doutorado do PPGCA, UFERSA, Mossoró, RN, Brasil. E-mail: andreia.m.silva@hotmail.com; arianapaivalc@yahoo.com.br

3 Discente, Curso de Graduação em Medicina Veterinária, UFERSA, Mossoró, RN, Brasil. E-mail: arthur_lago@hotmail.com

4 Profs., PPGCA, UFERSA, Mossoró, RN, Brasil. E-mail: valeria@ufersa.edu.br; alexsandra.pereira@ufersa.edu.br; legio2000@ yahoo.com

5 Prof., Departamento de Ciência Animal, Universidade Federal do Ceará, UFC, Fortaleza, CE, Brasil. E-mail: arlindo.moura@ gmail.com

* Author for correspondence 
- SOD e a catalase - CAT, são capazes de remover os agentes oxidativos antes que causem injúrias. O objetivo deste estudo foi investigar a atividade das enzimas SOD e CAT no plasma seminal, e sua associação com a qualidade espermática em catetos. O estudo foi conduzido durante o período seco (agosto a setembro) em uma região caracterizada pelo clima semiárido, com temperatura média anual de $27^{\circ} \mathrm{C}$ e pluviosidade irregular (Mossoró, RN, Brasil; $5^{\circ} 10^{\prime} \mathrm{S}$ e $37^{\circ} 10^{\prime} \mathrm{W}$ ). Nove ejaculados foram obtidos de machos sexualmente maduros ( 1 amostra por animal) por eletroejaculação. $\mathrm{O}$ sêmen foi avaliado quanto aos parâmetros microscópicos e a atividade da SOD e da CAT foi mensurada por espectrofotometria. Todos os ejaculados apresentavam coloração branca. Os valores médios para a concentração foram de $207 \pm 160 \times 10^{6}$ espermatozoides $/ \mathrm{mL}$, motilidade de $83,0 \pm 20,9 \%$ e viabilidade de $72,5 \pm 10,4 \%$. No que diz respeito à atividade enzimática, nenhuma foi observada para a enzima CAT. Traços de SOD $(0,033 \pm 0,049 \mathrm{AU} / \mathrm{mgP})$ foram detectados nos ejaculados de todos os indivíduos; entretanto, nenhuma correlação foi observada entre os níveis de SOD e a motilidade espermática ( $R$ $=0,35 ; \mathrm{P}=0,931)$, o vigor $(\mathrm{R}=0,29 ; \mathrm{P}=0,133)$, a viabilidade $(\mathrm{R}=0,16 ; \mathrm{P}=0,29)$, a função de membrana $(R=0,04 ; P=0,617)$ ou a morfologia espermática $(R=003 ; P=0,637)$. Em conclusão, nós demonstramos a primeira descrição da atividade enzimática antioxidante no plasma seminal de ejaculados frescos obtidos de catetos. A atividade da SOD foi evidente durante o período seco de uma região semiárida, mas nenhuma relação entre a SOD e os parâmetros seminais foi observada.

Palavras-chave: Estresse oxidativo. Sêmen. Mamíferos silvestres. Biobanco.

\section{Introduction}

Seminal plasma serves as a carrier of sperm through the female reproductive tract, providing conditions necessary for the maintenance and viability of the sperm in order for fertilization to occur. In this sense, the composition of the seminal fluid, which results from the prostate, seminal vesicle, and bulbourethral gland secretions (GARCIA et al., 2000), has a significant influence on semen quality (KAZIOROWSKA-GILUN et al., 2016). Seminal plasma contains sugars, lipids, electrolytes (LEAHY; DE GRAAF, 2012), fertilityassociated proteins (MONTANHOLI et al., 2016), and antioxidant enzymes (ZAJA et al., 2016). The seminal plasma components have a positive effect on sperm quality, and a protective effect on seminal functions (KAZIOROWSKA-GILUN et al., 2016). Previous studies in several species suggest that seminal plasma also contains antioxidant factors that may influence sperm motility and viability (MARTI et al., 2007; ZAJA et al., 2016).

The ability of sperm to fertilize an oocyte is affected by motility, concentration, and morphology, which all may be negatively impacted by oxidative stress (VERNET et al., 2004). Therefore, the antioxidant properties of seminal plasma have an important role in the protection of sperm against damage caused by reactive oxygen species (ROS) that are normally produced in all living cells (STRZEZEK et al., 2005). The study of the antioxidant enzymes helps to define the mechanisms by which sperm is influenced by ROS.

ROS may have both positive and negative effects on sperm. Positive examples include roles in regulating sperm hyperactivation due to acrosome reactions, and in the interaction of sperm with the oocyte (SENGOKU et al., 1998). On the other hand, a negative impact occurs when excessive amounts of ROS promote oxidative stress, resulting in damage to sperm membranes through lipid peroxidation (AITKEN et al., 1993). This damage may be lessened by an antioxidant system, such as the action of superoxide dismutase (SOD) and catalase (CAT), which are capable of removing the oxidizing agents before they cause injuries (VALENÇA; GUERRA, 2007).

Antioxidant enzyme activity in seminal plasma has been described in several species, including humans (SANOCKA et al., 1996), canines (CASSANI et al., 2005), equines (KANKOFER et al., 2005), sheep (MARTI et al., 2007), and swine (KAZIOROWSKA-GILUN et al., 2011). It is also 
known that factors associated with the species (STRZEZEK et al., 2009; KAZIOROWSKAGILUN et al., 2011), the breed (ZAJA et al., 2016), the season (STRZEZEK et al., 2002), nutrition (BINDER et al., 2015), and thermoregulation (ROCHA et al., 2015) may affect the activity of antioxidant enzymes in seminal plasma. In this regard, the identification of antioxidant enzyme activities is an important step in defining the reproductive physiology of a species, especially for a wild animal such as the collared peccary (Pecari tajacu Linnaeus, 1758). Such knowledge is important for the improvement of sperm cryopreservation (CASTELO et al., 2010; ALVES et al., 2012; SOUZA et al., 2016) and artificial insemination (PEIXOTO et al., 2017) protocols, which are essential for the reproduction and conservation of the species.

Several factors justify the studies related to the use of assisted-reproductive technologies in collared peccaries. This wild porcine species is highly adaptable to captivity, and is of economic interest due to the commercial potential of its meat (REDFORD, 1992) and leather (BODMER; PEZO, 1999). Moreover, its management in captivity using sustainable practices may serve as an alternative for rural producers (SANTOS et al., 2009). Beyond commercial benefits, collared peccaries may be useful as experimental models because of their close relation to endangered species such as Tayassu pecari and Catagonus wagneri (IUCN, 2017).

Further understanding of the reproductive biology of peccaries will be beneficial in the development of conservation and husbandry strategies. The aim of the current study was to investigate the activity of antioxidant enzymes SOD and CAT in seminal plasma, and their association with sperm quality.

\section{Material and Methods}

This study was approved by the Ethics Committee of Animal Use of the Federal Rural University of Semiarid (CEUA/UFERSA, $\mathrm{n}^{\circ}$ 23.091.0254/11-
88). All procedures were designed according to the guidelines for the ethical use of animals in research (ASSOCIATION FOR THE STUDY OF ANIMAL BEHAVIOUR, 2006).

\section{Experimental location and period}

All procedures for semen collection and evaluation were performed in the Center of Wild Animals Multiplication (CEMAS) and Laboratory of Animal Germplasm Conservation, both of the Federal Rural University of Semiarid and located at the semiarid region of Brazil (Mossoro, RN: $\left.5^{\circ} 10^{\prime} \mathrm{S}, 37^{\circ} 10^{\prime} \mathrm{W}\right)$. This region presents an annual average temperature of approximately $27^{\circ} \mathrm{C}$ and it is characterized by irregular rainfall that is usually distributed in a short period of only three months, followed by a large dry period (SILVA et al., 2011). All enzyme analysis were conducted in the Department of Animal Science of the Federal University of Ceará, Brazil. The semen collection was conducted during the peak of the dry period (August and September).

\section{Animals and management}

Nine sexually mature male collared peccaries with an average $( \pm \mathrm{SD})$ age of $21.0 \pm 1.0$ months and weight of $20.0 \pm 0.1 \mathrm{~kg}$ were isolated from females 6 months before the commencement of the experiment. They were maintained outdoors in groups of 4 and 5 in paddocks $(20 \times 3 \mathrm{~m})$ with a covered area of $3 \times 3 \mathrm{~m}$ under a $12 \mathrm{~h}$ natural photoperiod. Animals were fed with swine food and fruits and water was provided ad libitum.

\section{Semen collection and evaluation}

For semen collection, animals were fasted $12 \mathrm{~h}$ before the experiments began. Then, they were physically restrained using a hand net and anesthetized using intravenous administration of propofol (Propovan, Cristalia, Fortaleza, Brazil), 
given as a bolus at $5 \mathrm{mg} / \mathrm{kg}$ (SOUZA et al., 2009). The individuals were kept in lateral recumbency, and semen was collected by electroejaculation (Autojac, Neovet, Campinas, Brazil) as described by Castelo et al. (2010). Semen was collected in plastic tubes and immediately evaluated.

All semen samples were evaluated for aspect and volume. Then, a $5 \mu \mathrm{L}$ aliquot was diluted in $10 \%$ buffered formalin $(1 \mathrm{~mL})$ and sperm concentration was determined using a Neubauer counting chamber (SILVA et al., 2014). Sperm motility was assessed by evaluating a sample $(5 \mu \mathrm{L})$ using light microscopy under $\times 100$ and $\times 400$ magnification. The sperm vigor was evaluated using a scale of 0 to 5 , with 0 and 5 characterized by no movement and progressive forward movement, respectively. Brome-phenol blue-stained smears were prepared with $5 \mu \mathrm{L}$ of semen for evaluating sperm viability and morphology using light microscopy $(\times 1000)$, counting 100 cells (CAMPOS et al., 2017). Finally, the functional integrity of the sperm membrane was evaluated by its osmotic response to a hyposmotic swelling test, using distilled water $(0 \mathrm{mOsm} / \mathrm{L})$ as the hyposmotic solution, counting 200 cells per slide (SANTOS et al., 2013).

After initial analysis, the seminal plasma was obtained by centrifugation at $700 \times \mathrm{g}$ for $10 \mathrm{~min}$. The supernatant was transferred to microtubes $(1.5$ $\mathrm{mL}$ ) and stored at $-20^{\circ} \mathrm{C}$ until enzyme assays.

\section{Antioxidant enzymatic assays}

Antioxidant enzymatic activity of each seminal plasma sample was measured. The activity of two enzymes, superoxide dismutase (SOD) and catalase (CAT), was analyzed using $40-50 \mu \mathrm{L}$ of seminal plasma.

\section{SOD activity}

SOD activity was measured according to the protocol used by Kaziorowska-Gilun et al. (2011) for porcine seminal plasma. The reaction mixture consisted of $0.5 \mathrm{M}$ sodium phosphate buffer $(\mathrm{pH}$ 7.8), $0.50 \%$ Triton X-100, $130 \mathrm{mM}$ L-methionine, $2.0 \mathrm{mM}$ EDTA, $0.75 \mathrm{mM}$ nitro blue tetrazolium (NBT), $1.0 \mathrm{mM}$ riboflavin and milli-Q water. This mixture was exposed to light $(32 \mathrm{~W}$ fluorescent circular lamp) for five minutes to initiate the reaction. The production of blue formazan was measured by the absorbance that was read under $630 \mathrm{~nm}$ wave provided by an ELISA reader (Automated Microplate Reader, model ELX800Bio-Tek Instruments ${ }^{\circledR}$, Inc.). A blank control test was performed, in which all reagents were used, except the seminal plasma, when the maximum reduction of NBT occurs. The enzyme activity was determined according to its capacity of inhibiting the formation of blue formazan. The activity unity (AU) was defined as the necessary quantity of the sample to inhibit $50 \%$ of the photo reduction (related to the positive control) of NBT to blue formazan (BEAUCHAMP; FRIDOVICH, 1971) and expressed as activity unity per milligrams of protein $(\mathrm{AU} / \mathrm{mgP})$.

\section{CAT activity}

CAT activity was measured according to the methods designed by Kaziorowska-Gilun et al. (2011) for porcine seminal plasma. The enzymatic activity was determined by following the decrease in absorbance at $240 \mathrm{~mm}$ (Genesys 10S UV-VIS spectrophotometer of Thermo Scientific), with $30 \mathrm{sec}$ interval at $30^{\circ} \mathrm{C}$, using $36 \mathrm{M}^{-1} \mathrm{~cm}^{-1}$ molar extinction coefficient, expressed by micromoles of $\mathrm{H}_{2} \mathrm{O}_{2}$ per protein milligram $\left(\mu \mathrm{mol} \mathrm{H}_{2} \mathrm{O}_{2} / \mathrm{mgP}\right.$ ). The reaction mixture consisted of $75 \mathrm{mM}$ sodium phosphate buffer ( $\mathrm{pH}$ 7.0) and $12.5 \mathrm{mM} \mathrm{H}_{2} \mathrm{O}_{2}$.

\section{Data analysis}

The results were expressed as means ( \pm S.D.) and analyzed by Statview 5.0 software (SAS Institute Inc., Cary, USA). For all evaluations, nine replicates 
(1 anima1/1 ejaculate/1 replicate) were considered for the analysis of data. A simple linear regression model was used to identify associations between enzyme activity (independent variables) and sperm parameters (dependent variables). $\mathrm{P}<0.05$ was considered significant.

\section{Results}

Fresh ejaculates obtained from nine male collared peccaries presented as fluid with a watery aspect, white in color, and an average volume of $2.0 \pm 1.1$ $\mathrm{mL}$. The mean concentration of the specimens was $207 \times 10^{6}\left( \pm 160.7 \times 10^{6}\right) \mathrm{sperm} / \mathrm{mL}$. The quantitative aspects of the sperm, including motility, vigor, viability, morphology, and functional, membrane are shown in Table 1.

Table 1. Sperm characteristics (mean \pm S.D.) observed in fresh ejaculates derived from collared peccaries $(n=9)$ collected by electroejaculation during the dry period in a semiarid region.

\begin{tabular}{cc}
\hline Sperm characteristics & Mean \pm S.D. \\
\hline Motility (\%) & $83.0 \pm 20.9$ \\
Vigor (0-5) & $4.2 \pm 1.1$ \\
Viability (\%) & $72.5 \pm 10.4$ \\
Cells with functional membrane (\%) & $80.4 \pm 14.1$ \\
Normal morphology (\%) & $80.0 \pm 21.0$ \\
\hline
\end{tabular}

In regard to enzymatic activity, none was detected for the CAT enzyme. Trace levels of SOD $(0.033 \pm 0.049 \mathrm{AU} / \mathrm{mgP})$ were detected in the ejaculates of all individuals (Table 2). No correlation was observed between SOD levels and the sperm quantitative parameters of motility $(\mathrm{R}=0.35 ; \mathrm{P}=$ $0.931)$, vigor $(\mathrm{R}=0.29 ; \mathrm{P}=0.133)$, viability $(\mathrm{R}=$ $0.16 ; \mathrm{P}=0.29)$, functional membrane $(\mathrm{R}=0.04 ; \mathrm{P}=$ $0.617)$ or morphology $(\mathrm{R}=0.03 ; \mathrm{P}=0.637)$.

Table 2. Superoxide dismutase (SOD) activity in the seminal plasma derived from collared peccaries $(\mathrm{n}=9)$ during dry period in a semiarid region.

\begin{tabular}{cc}
\hline Animals & SOD (AU/mgP) \\
\hline 1 & 0.11 \\
2 & 0.03 \\
3 & 0.03 \\
4 & 0.02 \\
5 & 0.05 \\
6 & 0.03 \\
7 & 0.03 \\
8 & -0.07 \\
9 & 0.07 \\
\hline Mean \pm S.D. & $0.033 \pm 0.049$
\end{tabular}




\section{Discussion}

To the best of our knowledge, this is the first study to investigate the activity of antioxidant enzymes in the seminal plasma of collared peccaries detecting no activity for the CAT enzyme and only traces of SOD activity. Because this study was conducted during the dry period of a semi-arid region, CAT may not have been synthesized, or may have been inactive. Other compensatory mechanisms that protect sperm cells from ROS attack are likely. This is supported by the significant presence of glutathione peroxidase (GPx) found in the seminal plasma proteome of the same species that was used in the current study (SANTOS et al., 2014), and in domestic swine (KAZIOROWSKA-GILUN et al., 2011). It is well known that in biological systems, SOD activity is usually associated with GPx or CAT activity (KAZIOROWSKA-GILUN et al., 2016). In this context, we hypothesize that the antioxidant system in the seminal plasma of collared peccaries requires the association of both GPx, as previously described for this species (SANTOS et al., 2014), and SOD activity, newly identified in the present study.

Many factors such as the breed (ZAJA et al., 2016), photoperiod (SANCHO et al., 2004), season (STRZEZEK et al., 2002) and temperature (KAZIOROWSKA-GILUN et al., 2011) influence the composition of swine seminal plasma. Swine is the domestic species most phylogenetically related to the peccaries (BENIRSHCHKE, 1974), and their seminal plasma compositions may be similarly influenced. Strzezek et al. (2002) found that the protein quantities in swine seminal plasma are reduced during the warm period of the year, and increase during winter and autumn; providing protectant effects to the sperm and assisting to maintain sperm function. In swine, SOD is highly requested during the sperm stocking, which provides greater protection during spring and summer compared to winter and autumn (KAZIOROWSKA-GILUN et al., 2011). This may also occur in collared peccaries, which may explain the low enzyme activity detected in their seminal plasma during the dry period in a semiarid region (0.033 AU/mgP), when compared to domestic swine $(39.4 \mathrm{U} / \mathrm{mL})$ using the same methodology (KAZIOROWSKA-GILUN et al., 2011). It is important to note, however, that species-related factors may also influence the levels of SOD in seminal plasma. Wild boar/domestic pig hybrids have low SOD levels $(1.47 \mathrm{U} / \mathrm{mL}$ ) (DZIEKOŃSKA et al., 2014) compared to domestic swine (0.79-1.44 $\mathrm{U} / \mathrm{mL}$ ), which have levels close to those found in rams (MARTI et al., 2007).

In a previous study performed in Texas in subtropical weather, sperm motility of individual collared peccaries varied from $5 \%$ to $90 \%$ with higher proportions of motile cells being present during spring, and lower proportions during summer (HELLGREN et al., 1989). On the other hand, in the Brazilian Amazon in equatorial weather, reproductive seasonality does not occur in collared peccary males (KAHWAGE et al., 2010). In collared peccaries raised under semiarid conditions of the Caatinga biome, in the same biome as our work, preliminary results suggest a possible influence of seasonality on the efficiency of semen collection in eleven, sexually mature males that were monitored monthly from September 2015 to June 2016 (MAIA et al., 2017). Although more studies are needed, seasonal effects on seminal composition in collared peccaries may be similar to that of swine (KAZIOROWSKA-GILUN et al., 2011).

As previously mentioned, we detected no CAT activity in the seminal plasma from collared peccaries. Various levels of CAT are described in studies using several different species. In domestic swine, SOD activity demonstrates marked variations in the seminal plasma according to the seasonal period, but the same is not observed for CAT activity, which is steady and at extremely low levels of 1.6 to $2.1 \mathrm{U} / \mathrm{mL}$ (KAZIOROWSKA-GILUN et al., 2011). These values in swine seminal plasma are the lowest observed compared to those in reproductive-tract fluids collected from the cauda epididymis (4.2- 
$18.9 \mathrm{U} / \mathrm{mL})$ or vesicular glands $(2.4-9.0 \mathrm{U} / \mathrm{mL})$, which seasonally vary (KAZIOROWSKA-GILUN et al., 2011). Consistent with our findings, Strzezek et al. (2009) failed to detect CAT activity in dog semen. Moreover, the yellow fraction of red deer semen exhibits SOD activity, but not CAT activity (KAZIOROWSKA-GILUN et al., 2016). Contrary to this, CAT activity in ram seminal plasma varies during seasonal periods with values ranging from 8.73 to $16.7 \mathrm{U} / \mathrm{mL}$ (MARTI et al., 2007). Differing origins of the enzymes may account for the variations observed. For instance, SOD may be primarily secreted by the prostate, while CAT may be from a multi-glandular origin (YEUNG et al., 1998).

SOD is the most abundant enzyme in biological systems (HALLIWELL, 2006) and acts in the dismutation of the superoxide anion $\left(\mathrm{O}_{2}^{-}\right)$in oxygen $\left(\mathrm{O}_{2}\right)$ and hydrogen peroxide $\left(\mathrm{H}_{2} \mathrm{O}_{2}\right)$, metabolites that participate in $\mathrm{OH}$ production (NISHIKIMI; MACHLIN, 1975). This action prevents lipid peroxidation in spermatozoa of several species (VALENÇA; GUERRA, 2007). On the other hand, CAT is an intracellular enzyme belonging to the subclass of oxidoreductase enzymes that use peroxide as a receptor and electron donor (BARREIROS et al., 2006) and catalyzes the reduction of $\mathrm{H}_{2} \mathrm{O}_{2}$ to $\mathrm{H}_{2} \mathrm{O}$ and $\mathrm{O}_{2}$ (FERREIRA; MATSUBARA, 1997). Both enzymes act to detoxify the oxidizing agents before they cause cell damage (GUERRA et al., 2012). Halliwell (2006) showed that CAT, while not directly involved in the elimination of ROS, inactivates $\mathrm{H}_{2} \mathrm{O}_{2}$, inhibiting its conversion to $\mathrm{OH}$, which may attack spermatozoa molecules. CAT acts only when there are elevated $\mathrm{H}_{2} \mathrm{O}_{2}$ levels (VERNET et al., 2004).

Importantly, ROS may have beneficial effects when present in adequate levels (DE LAMIRANDE; GAGNON, 1993). Studies on bovine sperm suggest that oxygen derivatives are involved in sperm capacitation, and that low concentrations of $\mathrm{H}_{2} \mathrm{O}_{2}$ modify the membrane and induce acrosome reactions (O'FLAHERTY et al., 1999). In murine sperm, low peroxidative conditions, which do not alter sulfhydryl groups or in sperm motility, increase the fertilizing potential of these cells by increasing their capacity to bind to the zona pellucida (KODAMA et al., 1996). The seminal plasma mechanisms that regulate ROS must equilibrate by occasionally degrading themselves to avoid excessive levels. However, under certain situations, these mechanisms must be attenuated in order for ROS to perform its contributory role in reproductive physiology.

Results from our study found no relationship between SOD and spermatozoa in collared peccaries. Nevertheless, previous studies report a role for antioxidant systems in the maintenance of seminal conditions. In humans, disturbances between ROS levels and seminal plasma antioxidant contents lead to oxidative stress and male infertility (DOROSTGHOAL et al., 2017). Furthermore, Zaja et al. (2016) observed differences in semen variables among boar breeds and hybrids, and in their correlation to semen quality, demonstrating that biochemical and antioxidant defense indicators are probably inheritable traits.

The present study helps to define the reproductive physiology of collared peccaries, and to generate new insight into what is needed in order to reveal the processes behind sperm protection in this species. For instance, studies aimed at identifying the enzymatic activity during different periods of the year, or investigation of other reproductive fluids may be appropriate for future studies. Understanding the enzymatic protectant mechanisms of sperm may aid in the establishment of more efficient chilling or freezing protocols; improvements in sperm purification; and development of enzyme supplementation into sperm extender as needed, ultimately increasing sperm longevity and enhancing sperm conservation. 


\section{Conclusions}

This study demonstrated the first description of antioxidant enzyme activity in seminal plasma of fresh ejaculates obtained from collared peccaries. SOD antioxidant activity was evident during the dry period of a semiarid region, but no relationship between SOD and semen parameters was observed. Other compensatory mechanisms protecting collared peccaries sperm from ROS attack are likely.

\section{Acknowledgments}

This study was supported by National Counsel of Technological and Scientific Development (CNPq, process no. 558317/2009-0). The authors thank the Centre for Wild Animals Multiplication (CEMAS/ UFERSA) for providing the animals. AR Silva and AAAN Moura were recipients of $\mathrm{CNPq}$ grants.

\section{References}

AITKEN, R. J.; HARKISS, D.; BUCKINGHAM, D. Relationship between iron catalysed lipid peroxidation potential and human sperm function. Journal of Reproduction and Fertility, Oxford, v. 98, n. 1, p. 257265, 1993.

ALVES, H. M.; OLIVEIRA, I. R. S.; CASTELO, T. S.; LIMA, G. L.; SOUZA, A. L. P.; MOREIRA, M. A. P.; PAULA, V. V.; SILVA, A. R. Comparison of different glycerol and egg yolk concentrations added to tris-based extender for the collared peccaries (Tayassu tajacu) semen freezing. Reproduction in Domestic Animals, Oxford, v. 48, n. 3, p. 506-511, 2012.

ASSOCIATION FOR THE STUDY OF ANIMAL BEHAVIOUR. Guidelines for the treatment of animals in behavioral research and teaching. Animal Behaviour, New York, v. 71, n. 1, p. 245-253, 2006.

BARREIROS, A. L. B. S.; DAVID, J. M.; DAVID, J. P. Estresse oxidativo: relação entre geração de espécies reativas e defesa do organismo. Química Nova, São Paulo, v. 29, n. 1, p. 113-123, 2006.

BEAUCHAMP, C.; FRIDOVICH, I. Superoxide dismutase: improved assays and an assay applicable to acrylamide gels. Analytical Biochemistry, Oxford, v. 44, n. 1, p. 276-287, 1971.
BENIRSHCHKE, K. Quest for the giant peccary: the chaco revisited. Zoonoz, Oxford, v. 25, n. 1, p. 364-372, 1974.

BINDER, N. K.; SHEEDY, J. R.; HANNAN, N. J.; GARDNER, D. K. Male obesity is associated with changed spermatozoa cox mRNA level and altered seminal vesical fluid composition in a mouse model. Molecular Human Reproduction Advance, Oxford, v. 21, n. 5, p. 424-434, 2015.

BODMER, R. E.; PEZO, E. Análisis económico del uso de fauna silvestre em la Amazonía Peruana. In: FANG, T. G.; MONTENEGRO, O. L.; BODMER, R. E. (Ed.). Manejo y conservación de fauna silvestre en América Latina. Santa Cruz: Editorial Instituto de Ecología, 1999. p. 171-182.

CAMPOS, L. B.; PEIXOTO, G. C. X.; SILVA, A. M.; SOUZA, A. L. P.; CASTELO, T. S.; MAIA, K. M.; PEREIRA, A. F.; SILVA, A. R. Estimating the binding ability of collared peccary (Pecari tajacu Linnaeus, 1758) sperm using heterologous substrates. Theriogenology, Oxford, v. 92, n. 1, p. 57-62, 2017.

CASSANI, P.; BECONI, M. T.; O'FLAHERTY, C. Relationship between total superoxide dismutase activity with lipid peroxidation, dynamics and morphological parameters in canine semen. Animal Reproduction Science, Oxford, v. 86, n. 1-2, p. 163-173, 2005.

CASTELO, T. S.; BEZERRA, F. S. B.; SOUZA, A. L. P.; MOREIRA, M. A. P.; PAULA, V. V.; OLIVEIRA, M. F.; SILVA, A. R. Influence of the thawing rate on the cryopreservation of semen from collared peccaries (Tayassu tajacu) using Tris-based extenders. Theriogenology, Oxford, v. 74, n. 6, p. 1060-1065, 2010.

DE LAMIRANDE, E.; GAGNON, C. Human sperm hyperactivation and capacitation as parts of an oxidative process. Free Radical Biology and Medicine, Oklahoma, v. 14, n. 2, p. 255-265, 1993.

DOROSTGHOAL, M.; KAZEMINEJAD, S. R.; SHAHBAZIAN, N.; POURMEHDI, M.; JABBARI, A. Oxidative stress status and sperm DNA fragmentation in fertile and infertile men. Andrologia, New York, v. 49, n. 10, p. 1-9, 2017.

DZIEKOŃSKA, A.; FRASER, L.; KOZIOROWSKAGILUN, M.; STRZEZEK, J.; KOZIOROWSKI，M; KORDAN, M. Seasonal-dependent variations in metabolic status of spermatozoa and antioxidant enzyme activity in the reproductive tract fluids of wild boar/ domestic pig hybrids. Polish Journal of Veterinary Sciences, Warszawa, v. 17, n. 2, p. 307-313, 2014. 
FERREIRA, A. L. A.; MATSUBARA, J. S. Radicais livres: conceitos, doenças relacionadas, sistema de defesa e estresse oxidativo. Revista da Associação Médica Brasileira, São Paulo, v. 43, n. 1, p. 61-68, 1997.

GARCIA, L.; ACEVEDO, M.; ROSSINI, M. Aspectos histológicos del tracto genial masculino del baquiro de colar. III. Características de las glândulas anexas. Veterinaria Tropical, Goiânia, v. 25, n. 2, p. 277-284, 2000.

GUERRA, M. M. P.; CÂMARA, D. R.; SILVA, E. C. B.; SILVA, S. V. Use of antioxidants on ram sêmen. Ciência Animal, Fortaleza, v. 22, n. 1, p. 354-364, 2012.

HALLIWELL, B. Oxidative stress and neurodegeneration: where are we now? Journal of Neurochemistry, Medford, v. 97, n. 6, p. 1634-1658, 2006.

HELlGREN, E. C.; LOCHMILLER, M. S.; AMOSS, J. R.; GRANT, W. E. Seasonal variation in serum testosterone, testicular measurement and semen characteristics in the collared peccary (Tayassu tajacu). Journal of Reproduction and Fertility, Oxford, v. 85, n. 1, p. 677-686, 1989.

INTERNATIONAL UNION FOR THE CONSERVATION OF NATURE - IUCN. The IUCN RED LIST OF THREATENED SPECIES. Version 2015.4. Cambridge: IUCN Global Species Programme Red List Unit, 2017. Available at: <http://dx.doi.org/10.2305/ IUCN.UK.2015-2.RLTS.T4015A72587993.en>. Access at: 27 mar. 2017.

KAHWAGE, P. R.; GARCIA, A. R.; GUIMARÃES, D. A. A.; OHASHI, O. M.; LUZ-RAMOS, R. S.; DIAS, H. L. T.; ALBUQUERQUE, N. I.; BARTHA, M. M. P. Biometria testicular, eletroejaculação e características seminais de caititus, Tayassu tajacu Linnaeus, 1758 (Mammalia, Artiodactyla, Tayassuidae) mantidos em cativeiro na Amazônia Oriental. Acta Amazônia, Manaus, v. 40, n. 4, p. 771-778, 2010.

KANKOFER, M.; KOLM, G.; AURICH, J.; AURICH, C. Activity of glutathione peroxidase, superoxide dismutase and catalase and lipid peroxidation intensity in stallion semen during storage at $5^{\circ} \mathrm{C}$. Theriogenology, Oxford, v. 63, n. 5, p. 1354-1365, 2005.

KAZIOROWSKA-GILUN, M.; KOZIOROWSKI, M.; STRZEZEK, J.; FRASER, L. Seasonal changes in antioxidant defence systems in seminal plasma and fluids of the boar reproductive tract. Reproductive Biology, Oxford, v. 11, n. 1, p. 37-47, 2011.

KAZIOROWSKA-GILUN, M.; SZURNICKA, M.; DZIEKONSKA, A.; KORDAN, W.; GIEJEWSKI, Z; FILIPOWICZ, K. Characteristics of antioxidant systems of yellow fraction of red deer's (Cervus elaphus
L.) semen during the rutting period. Reproduction in Domestic Animals, New York, v. 51, n. 2, p. 248-254, 2016.

KODAMA, H.; KURIBAYASHI, Y.; GAGNON, C. Effect of sperm lipid peroxidation on fertilization. Journal of Andrology, Hoboken, v. 17, n. 2, p. 151-157, 1996.

LEAHY, T.; DE GRAAF, S. P. Seminal plasma and its effect on ruminant spermatozoa during processing. Reproduction in Domestic Animals, Oxford, v. 47, n. 4, p. 207-213, 2012.

MAIA, K. M.; SOUZA, A. L. P.; SILVA, A. M.; PRAXEDES, E. C. G.; CAMPOS, L. B.; BEZERRA, L. G. P.; MOREIRA, S. S. J.; APOLINARIO, C. A. C.; SANTOS, T. J. A.; SOUZA, J. B. F.; OLIVEIRA, M. F.; SILVA, A. R. Seasonal variation of electroejaculatory response and semen parameters of collared peccaries (Pecari tajacu) bred under semiarid conditions. Animal Reproduction, Belo Horizonte, v. 14, n. 1, p. 363, 2017.

MARTI, E.; MARA, L.; MARTI, J. I.; MUIÑOBLANCO, T.; CEBRIÁN-PÉREZ, J. A. Seasonal variations in antioxidant enzyme activity in ram seminal plasma. Theriogenology, Oxford, v. 67, n. 9, p. 14461454, 2007.

MONTANHOLI, Y. R.; FONTOURA, A. B. P.; DIEL DE AMORIM, M.; FOSTER, R. A.; CHENIER, T.; MILLER, S. P. Seminal plasma protein concentrations vary with feed efficiency and fertility-related measures in young beef bulls. Reproductive Biology, Oxford, v. 16, n. 2, p. 147-156, 2016.

NISHIKIMI, M.; MACHLIN, L. J. Oxidation of $\alpha$-tocopherol model compound by superoxide anion. Archives of Biochemistry and Biophysics, Oxford, v. 170, n. 1, p. 684-689, 1975.

O'FLAHERTY, C. M.; BEORLEGUI, N. B.; BECONI, M. T. Reactive oxygen species requirements for bovine sperm capacitation and acrosome reaction. Theriogenology, Oxford, v. 52, n. 2, p. 289-301, 1999.

PEIXOTO, G. C. X.; PRAXEDES, E. C. G.; SILVA, A. M.; CAMPOS, L. B.; LAGO, A. E. A.; BEZERRA, L. G. P.; MOREIRA, S. S. J.; APOLINÁRIO, C. A. C.; BRITO, A. B.; DOMINGUES, S. F. S.; OLIVEIRA, M. F.; SILVA, A. R. Estrous synchronization followed by artificial insemination in collared peccaries (Pecari tajacu) - the first attempt. Animal Reproduction, Belo Horizonte, v. 14, n. 1, p. 148, 2017.

REDFORD, K. H. The empty forest. Bio Science, Oxoford, v. 42, n. 1, p. 412-422, 1992.

ROCHA, D. R.; MARTINS, J. A. M.; VAN TILBURG, M. F.; OLIVEIRA, R. V.; MORENO, F. B.; MONTEIRO- 
MOREIRA, A. C. O.; ARAUJO, A. A.; MOURA, A. A. Effect of increased testicular temperature on seminal plasma proteome of the ram. Theriogenology, Oxford, v. 84, n. 8, p. 1291-1305, 2015.

SANCHO, S.; PINART, E.; BRIZ, M.; GARCIA-GIL, N.; BADIA, E.; BASSOLS, J.; KADAR, E.; PRUNEDA, A.; BUSSALLEN, E.; YESTE, M.; COLL, M. G.; BONET, S. Semen quality of postpubertal boars during increasing and decreasing natural photoperiods. Theriogenology, Oxford, v. 62, n. 7, p. 1271-1282, 2004.

SANOCKA, D.; MIESEL, R.; JEDRZEJCZAK, P.; KURPISZ, M. K. Oxidative stress and male infertility. Journal of Andrology, Hoboken, v. 17, n. 4, p. 449-454, 1996.

SANTOS, D. O.; MENDES, A.; NOGUEIRA, S. S. C.; NOGUEIRA-FILHO, S. L. G. Criação comercial de caititus (Pecari tajacu): uma alternativa para o agronegócio. Revista Brasileira de Saúde e Produção Animal, Salvador, v. 10, n. 1, p. 1-10, 2009.

SANTOS, E. A. A.; SOUSA, P. C.; MARTINS, J. A. M.; MOREIRA, R. A.; MONTEIRO-MOREIRA, A. C. O.; MORENO, F. B. M. B.; OLIVEIRA, M. F.; MOURA, A. A.; SILVA, A. R. Protein profile of the seminal plasma of collared peccaries (Pecari tajacu Linnaeus, 1758). Reproduction, Oxford, v. 147, n. 1, p. 753-764, 2014.

SANTOS, E. A. A.; SOUSA, P. C.; PEIXOTO, G. C. X.; SIMÃO, B. R.; OLIVEIRA, M. F.; SILVA, A. R. Establishing the hypoosmotic swelling test for sperm analysis in collared peccaries (Pecari tajacu). Arquivo Brasileiro de Medicina Veterinária e Zootecnia, Belo Horizonte, v. 65, n. 4, p. 1257-1260, 2013.

SENGOKU, K.; TAMATE, K.; YOSHIDA, T.; TAKAOKA, Y.; MIYAMOTO, T.; ISHIKAWA, M. Effects of low concentrations of nitric oxide on the zona pellucida binding ability of human spermatozoa. Fertility and Sterility, Oxford, v. 69, n. 3, p. 522-527, 1998.

SILVA, A. M.; PEIXOTO, G. C. X.; BEZERRA, J. A. B.; CASTElO, T. S.; SANTOS, E. A. A.; SILVA, A. R. Relações entre a câmara de Neubauer a espectrofotometria utilizadas para a determinação da concentração espermática de catetos (Pecari tajacu). Ciência Rural, Santa Maria, v. 44, n. 1, p. 1494-1498, 2014.

SILVA, V. P. R.; PEREIRA, E. R. R.; AZEVEDO, P. V.; SOUSA, F. A. S.; SOUSA, I. F. Análise da pluviometria e dias chuvosos na região Nordeste do Brasil. Revista Brasileira de Engenharia Agrícola e Ambiental, Campina Grande, v. 15, n. 2, p. 131-38, 2011.
SOUZA, A. L. P.; CASTELO, T. S.; QUEIROZ, J. P. A. F.; BARROS, I. O.; PAULA, V. V.; OLIVEIRA, M. F.; SILVA, A. R. Evaluation of anesthetic protocol for the collection of semen from captive collared peccaries (Tayassu tajacu) by electroejaculation. Animal Reproduction Science, Oxford, v. 116, n. 3-4, p. 370-375, 2009.

SOUZA, A. L. P.; LIMA, G. L.; PEIXOTO, G. C. X.; SILVA, A. M.; OLIVEIRA, M. F.; SILVA, A. R. Use of Aloe Vera-based extender for chilling and freezing collared peccary (Pecari tajacu) semen. Theriogenology, Oxford, v. 85, n. 8, p. 1432-1438, 2016.

STRZEZEK， J.; KOZIOROWSKA-GILUN， M.; KOWALOWKA, M.; STRZEZEK, J. Characteristics of antioxidant system in dog semen. Polish Journal of Veterinary Sciences, Olsztyn, v. 12, n. 1, p. 55-60, 2009.

STRZEZEK, J.; SAIZ-CIDONCHA, F.; WYSOCKI, P. Seminal plasma proteins as markers of biological value of boar semen. Animal Science Papers and Reports, Jastrzębiec, v. 20, n. 4, p. 255-266, 2002.

STRZEZEK, J.; WYSOCKI, P.; KORDAN, W.; KUKLINSKA, M.; MOGIELNICKA, M.; SOLIWODA, D.; FRASER, L. Proteomics of boar seminal plasma current studies and possibility of their application in biotechnology of animal reproduction. Reproduction Science, Oxford, v. 5, n. 3, p. 279-290, 2005.

VALENÇA, R. M. B.; GUERRA, M. M. P. Espécies reativas de oxigênio (ROS) e a utilização de antioxidantes na criopreservação de sêmen suíno. Revista Brasileira de Reprodução Animal, Belo Horizonte, v. 31, n. 1, p. 147153, 2007.

VERNET, P.; AITKEN, R. J.; DREVET, J. R. Antioxidant strategies in the epididymis. Molecular and Cellular Endocrinology, Oxford, v. 216, n. 1-2, p. 31-39, 2004.

YEUNG, C.; COOPER, T.; GEYTER, M. de; GEYTER, C. de; ROLF, C.; KAMISCHKE, A.; NIESCHLAG, E. Studies on the origin of redox enzymes in seminal plasma and their relationship with results of in vitro fertilization. Molecular Human Reproduction, Childerley, v. 4, n. 9, p. 835-839, 1998.

ZAJA, I. V.; SAMARDZIJA, M.; VINCE, S.; VILIC, M.; MAJIC-BALIC, I.; DURICIC, D.; MILINKOVICTUR, S. Diferences in seminal plasma and spermatozoa antioxidative systems and seminal plasma lipid and protein levels among boar breeds and hybrid genetic traits. Animal Reproduction Science, Oxford, v. 170, n. 2, p. 75-82, 2016. 